\title{
BINDING FORCE OF CONSTITUTIONAL REVIEW DECISION OF CONSTITUTIONAL COURT TOWARD SUPREME COURT
}

\author{
Rian Van Frits Kapitan \\ Postgraduate Program Universitas Nusa Cendana \\ E-mail: ryankapitan@ymail.com
}

\begin{abstract}
The Supreme Court decision which sentenced dr. Bambang suprapto.Sp.M.Surg. using art-icle 76 of Law No 29 Year 2004 on the Practice of Medicine which had been annulled by the Constitutional Court has proved that the Supreme Court has put aside constitutional court's decision on constitutional review. This paper attempts to justify that at any reason, Constitutional Review decision of Constitutional Court still has binding force on the Su-preme Court. It is based on four perspectives: historical perspective, protected object perspective, functional perspective, and normative perspective.
\end{abstract}

Keywords: binding force, Constitutional Review, Constitutional Court, Supreme Court.

\begin{abstract}
Abstrak
Putusan Mahkamah Agung yang menghukum dr. Bambang Suprapto, Sp.M.Surg menggunakan Pasal 76 Undang-Undang Nomor 29 Tahun 2004 tentang Praktek Kedokteran yang sebelum-nya telah dibatalkan oleh Mahkamah Konstitusi dengan sendirinya telah membuktikan bah-wa Mahkamah Agung telah mengesampingkan putusan constitutional review Mahkamah Konstitusi. Tulisan ini mencoba untuk menjustifikasi bahwa dengan alasan apapun putusan constitutional review Mahkamah Konstitusi tetap mempunyai kekuatan mengikat bagi Mah-kamah Agung. Hal ini didasarkan atas empat perspektif, yaitu: perspektif historis, perspek-tif objek yang dilindungi, perspektif fungsional, dan perspektif normatif.
\end{abstract}

Kata kunci: kekuatan mengikat, Constitutional Review, Mahkamah Konstitusi, Mahkamah Agung.

Introduction

The public was shocked by the Supreme Court decision No. 1110 K/ Pid.Sus/ 2012 which sentenced dr. Bambang Suprapto, Sp.M.Surg to impose a prison sentence by using article 76 of Law Number 29 Year 2004 on Practice of Medicine. The problem is that Article 76 had been annulled by the Constitutional Court (Constitutional Court Decision Number 4/PUU-V/2007).

The Supreme Court's decision undoubtedly sparks controversy among legal practitioners and law scholars. Jimly Asshiddiqie, as former Chief of Constitutional Court stated that the judges who handled the case are incompetent. The Constitutional Court which is always considered as the constitutional guards ${ }^{1}$ implies

Dandi Handoyo, "Dinamika Putusan Mahkamah Konstitusi”, Jurnal Yudisial, Vol. IV, No. 8, April 2011, Jakarta: Komisi Yudisial, page 90. that the constitutional review surely has binding force including the Supreme Court. Therefore, the Supreme Court's decision that sentenced Dr. Bambang becomes the issue.

\section{Discussion}

Binding Force of Constitutional Review Decision of the Constitutional Court Toward the Supreme Court

History at least recorded that the Constitutional Court is an institution demanded in reform era as a result of long heated debate in the House of Representatives during the discussion of 1945 Constitution amendment.

Moh Mahfud MD proposed 7 (seven) the proposal of amendment for the 1945 Constitution, one of which is right establishment and expansion of Supreme Court including the right to conduct judicial review upon the laws and all 
legislations under their control. However, if the right burdens the Supreme Court, the Constitutional Court could be then formed. ${ }^{2}$

Mahfud's would provide contribution to the law development and Indonesia constitutional at that time. Due to the importance of judicial review, he stated that if it burdens Supreme Court, Constitutional Court can be then formed indeed. At least his suggestion could be accepted as a good alternative.

The Constitutional Court firstly emerged when the third amendment of the 1945 Indonesian Constitution was formulated. This agency serves as an independent state agency which is equal to the Supreme Court. This can be seen in Article 24 Paragraph (2) of the 1945 Indonesian Constitution amendments firmly states that: "Judicial power is performed by a Supreme Court and other judicial bodies in the public courts, religious courts, military courts, administrative courts and by a Constitutional Court." 3

According to Article 24 Paragraph (2) of The 1945 Constitution of the Republic of Indonesia, the Supreme Court and the Constitutional Court are simultaneously provide judicial power. Mahrus Ali pointed out that although the Supreme Court and the Constitutional Court have the same function, but they are different in institutional structure. The Supreme Court has wider scope due to several jurisdictions that Supreme Court oversees. ${ }^{4}$

The Constitutional Court Decision gained permanent legal force once it was declared in general plenary meeting. This is confirmed in Article 47 of Law Number 24 Year 2003 on the Constitutional Court. ${ }^{5}$

2 Moh. Mahfud MD, "Gagasan Pembentukan Mahkamah Konstitusi Republik Indonesia”, Jurnal Sintesis, Vol. 3, No. 9, May 1999, Jakarta: Faculty of Law Universitas Indonesia, page 18.

3 Bill Nope, "Pengawasan terhadap Hakim Konstitusi", Jurnal Konstitusi, Vol. III No. 1, June 2010, Jakarta: Mahkamah Konstitusi of Republic of Indonesia, page 127.

Mahrus Ali, "Mahkamah Konstitusi dan Penafsiran Hukum yang Progresif", Jurnal Konstitusi, Vol. 7, No. 1, February 2010, Jakarta: Mahkamah Konstitusi of Republic of Indonesia, page 72.

5 Slamet Tatang, "Mahkamah Konstitusi Sang Penjaga HAM", Jurnal Konstitusi, Vol. 11 No. 3, February 2009, Jakarta: Mahkamah Konstitusi of Republic of Indonesia, page 72 .
The descriptions above at least convince us that the constitutional review decision by the Constitutional Court actually has binding force for the Supreme Court. The Supreme Court that sentenced dr. Bambang using the annulled sentence clause by the Constitutional Court is a wrong decision. The author's argument is based on several perspectives.

\section{Historical Perspective}

The establishment of the Constitutional Court can be seen in the Academic Paper of Law Number 24 Year 2003 on Constitutional Court stated that: "'Some constitutional conflicts related to the implementation of institution authority based on 1945 Constitution, it can be argued here, for example, in President Soekarno and President Abdurrahman Wahid era. During that era, there was different interpretation upon the 1945 Constitution between the President and House of Representatives (DPR) related to issue of the President accountability. The case of President Soekarno era was related to G. $30 \mathrm{~S} / \mathrm{PKI}$, economic and moral degradation, while during the President Abdurrahman Wahid era were Bulog funds and the Sultan of Brunei Aid. President Soekarno delivered a speech $\mathrm{Na}$ waksara that he considered it a Progress Report not accountability report while President Abdurrahman Wahid declined to give his accountability in Special Assembly. Later both were then dismissed in Special Assembly of Temporary People's Consultative Assembly (MPRS). Although it is over, it left big question; which institution deserves to make an interpretation upon the 1945 Constitution. During this time, the final decision is mandated to Special Assembly but members of MPR are mostly members of Parliament, so their objectivity would be questionable. In this reason, the authority (such as impeachment) should involve assessment from other institutions namely the Constitutional Court. It includes the right to give a decision over the request of the House of Representatives based on the assessment showing that the President was no longer qualified as a

6 Naskah Akademik Undang-Undang No. 24 tahun 2003 tentang Mahkamah Konstitusi, page 2. 
President." Those illustrations are some thoughts of the relevance of the establishment of a Constitutional Court at that time. The issue of law constitutionalism is one of problems that was imposed on Constitutional Court at that time.

\section{Protected object perspective}

The Constitutional Court as a state institution is mandated an exclusive duty. The institute is in charge of maintaining and protecting the 1945 Constitution. The Constitutional Court's duties reflect in their authorities:

"The Constitutional Court has an authority to adjudicate in the first and last stage that is final decision to evaluate laws toward Constitution, solve dispute between state institutions authority granted by the Constitution, political parties dismissal, and to settle disputes concerning the results of general election ."7

The Supreme Court decision which contradicts to constitutional review decision of Constitutional Court is fatal because Supreme Court decision itself is contrary with the 1945 Constitution and Constitutional Court would interpret The 1945 Constitution as a guideline when deciding constitutional review case. Therefore, Constitutional Court decision equals to the laws and Constitutional Court decision contains a further interpretation from The 1945 Constitution. ${ }^{8}$

Titon Slamet Kurnia stated that Constitutional Court decision is actually an amendment of The 1945 Constitution. He supported his opinion with theoretical arguments that state constitution upheld by the judicial bodies, which is, through constitutionality test of Law, the judicial body decision would be potential to become one of the legitimate ways to constitution

Suharizal, "Penguatan Demokrasi Lokal Melalui Penghapusan Jabatan Wakil Kepala Daerah", Jurnal Konstitusi, Vol. 7 No. 5, Oktober 2010, Jakarta: Mahkamah Konstitusi of Republic of Indonesia, page 97.

8 Ni'matul Huda, "Pola Pengaturan Pemilukada dan Perluasan Keadilan Substantif”, Jurnal Konstitusi, Vol. 8 No. 2, April 2011, Jakarta: Mahkamah Konstitusi of Republic of Indonesia, page 34. "amendments" through constitutional interpretation accomplishments. ${ }^{9}$

Furthermore, no one can deny that The 1945 Constitution stated human rights principles which are implemented in every Articles. Including the human rights principle in The 1945 Constitution is a long process since the beginning of the Constitution was formed as there was different opinion between Muh. Yamin and Soekarno whether the human rights principles should be enclosed in The constitution or not.

Human rights norms in the Constitution has two positions namely as a steering and guiding norm for positive law to achieve ideals of human rights and as an evaluator of laws norm whether the positive law has been in accordance with the spirit of human rights. Furthermore Rudolf Stamler, a Neo Kantian philosopher, stated human rights norms contained in the Constitution are as a guiding star (Leitstern) for lawmakings underneath to stay in line with human rights values. ${ }^{10}$

Based on authority formulation of this institution, it is clear that the main object protected by this Court is the Constitution. Therefore, there is no reason for Supreme Court to disobey Constitutional Court decision in case of constitutional review, because it is strongly emphasized that protected object by Constitutional Court is the 1945 Constitution.

\section{Functional Perspective}

Based on institutional functional perspective, then it is true that Constitutional Court and Supreme Court are independent state agencies as the executive of judicial power. This can be seen in Article 24 Paragraph (2) of the 1945 Constitution which firmly stipulates: "Judicial power is performed by Supreme Court and judicial bodies underneath in the public courts, religious courts, military courts, administrative courts and by a Constitutional Court".

9 Titon Slamet Kurnia,2013, Mahkamah Konstitusi Republik Indonesia Sang Penjaga Ham (the guardian of human rights), Bandung: PT. Alumni, page 213-214.

10 Bambang Sutiyoso, "Pemihakan Hakim Terhadap Keadilan Susbstantif Dalam Penyelesaian Sengketa Kepemilikan Atas Tanah”, Jurnal Yudisial, Vol. 5 No. 3, December 2012, Jakarata: Komisi Yudisial, page 301. 
The question appears that "Is it because these two institutions have no hierarchical relationship, then one of the institution may set aside other decision?" This question is interesting to explore further as Supreme Court and Constitutional Court are independent state institutions.

These two institutions are independent so each should not set aside other decision, if it does, the independence of both institutions has been disrupted by itself. Both also function as executives of judicial power, consequently, a synergy must be established between them in carrying out their own authorities.

The Supreme Court that neglected the Constitutional Court decision was an act which does not maintain the independence of judicial power since such action would bring similar impact if it is carried out by either executive or legislative branches. The action itself has disrupted the Constitutional Court independence as one of the judicial power executive.

\section{Normative Perspective}

Article 47 of Law Constitutional Court determined: "The Constitutional Court had permanent legal power since stated in public plenary." It is then clear that Constitutional Court decision should be binding on the Supreme Court because the decision is final. If a Court decision has been unable to obtain legal remedy (appeal, cassation, and judicial review), the verdict is directly executed, isn't it? It is similar to motorcycle theft's case verdict that the defendant was sentenced to three years in prison by the Panel of Judges. When this verdict has had permanent legal force, so that the public prosecutor can directly execute the verdict. This is also applied to Constitutional Court verdict that even though the execution will not require a special apparatus, due to its permanent legal force, it will automatically bind the public. In addition, in Article 53 of the same Law also determines that: ${ }^{11}$ "The Constitutional Court told the Supreme Court petition for legis-

11 Satrio, "Erga Omnes Putusan Mahkamah Konstitusi", Jurnal Konstitusi, Vol. 11 No. V, March 2014, Jakarta: Mahkamah Konstitusi of Republic of Indonesia, page 101. lation review during not later than 7 (seven) working days after the application is recorded in "Constitution" Registry Book.

The authors argued if we read Article 53 thoroughly, it will obtain the same interpretation that this provision is intended to make Supreme Court and judicial bodies underneath know that the article or Law is being used to prosecute the case is being proposed to be reviewed in Constitutional Court. Then the next is Article 55 provision of Law which stated that Constitutional Court:

"Judicial review under Constitution being made by Supreme Court shall be terminated if the law as the basis of the review are in still in progress of Constitutional Court until there is a decision of the Constitutional Court."

The author argued that process of judicial review in Supreme Court should be discontinued if the basic legislation was cancelled by the Constitutional Court, and it is supported by the provisions of Article 58 of Law on the Constitutional Court stipulates that: "The Law which is reviewed by the Constitutional Court remains in force before there is a decision which states that Law is contrary to 1945 Indonesian Constitution. "Under the provisions of Article 58, it is clear that the Constitutional Court constitution designed as early as possible to overcome the emptiness which may occur in the future. Therefore the researchers might be objected if it is stated that Law Constitutional Court does not regulate in details towards the execution of a Constitutional Court verdict and also under of these normative provisions, it is clear that the Constitutional Court constitutional review decision has binding force on the Supreme Court.

Furthermore, another consideration as an affirmation towards the Constitutional Court decision is a provision in Article 57 Paragraph (3) of Law Number 24 Year 2003 on the Constitutional Court determines that: "The Constitutional Court decisions on a petition shall be published in State News during period not later than 30 (thirty) working days after the decision is made." 
The report of Constitutional Court verdict in the state news of the Republic of Indonesia aims to socialize the decision. It is similar to Law in which its legislation is conducted in State Gazette of Republic of Indonesia and published in State News of Republic of Indonesia thus to publicly socialize it.

Maria Farida Indrati Soeprapto stated that a legislation that has been legitimated or assigned will be binding applied when the legislation was enacted in a State Gazette or published in a State News. ${ }^{12}$ According to this view, authors agree with Hadi Kurniawan, that if the constitutions is directly in force once published in State Gazette of Republic of Indonesia and State News of Republic of Indonesia, then Constitutional Court verdict has the same philosophical purpose when published in State News of Republic of Indonesia. ${ }^{13}$ The nature of the legislation and Constitutional Court verdict is similar namely a public binding (erga omnes). It makes the verdict of the Constitutional Court equally with legislation accordingly.

\section{Conclusion}

Based on the descriptions above, it could be concluded that based on historical perspective, protected objects perspective, functional perspective, and normative perspective, constitutional review decision of Constitutional Court has binding force on Supreme Court.

\section{Suggestion}

Based on the conclusion above, the suggestion for this paper would be: Supreme Court as one of judicial power in deciding cases should always synchronize with the constitutional review decision of Constitutional Court, for any reason of the Constitutional Court shall be binding with Supreme Court. It aims to maintain the consistency of law in Indonesia.

\section{References}

12 Maria Farida Indrati Soeprapto, 1998, Ilmu PerundangUndangan, Dasar-dasar dan pembentukannya, Yogyakarta: Kanisius, page 176.

13 Hadi Kurniawan, "Dinamika Putusan Mahkamah Konstitusi”, Jurnal Konstitusi, Vol. 3, No. 4, 12 February 2008, Jakarta: Constitutional Court of Republic of Indonesia, page 53 .
Ali, Mahrus. "Mahkamah Konstitusi dan Penafsiran Hukum yang Progresif". Jurnal Konstitusi. Vol. 7 No. 1. February 2010. Jakarta: Mahkamah Konstitusi of Republic of Indonesia;

Handoyo, Dandi. "Dinamika Putusan Mahkamah Konstitusi”. Jurnal Yudisial. Vol. IV No. 8. April 2011. Jakarta: Komisi Yudisial;

Huda, Ni'matul. "Pola Pengaturan Pemilukada dan Perluasan Keadilan Substantif”. Jurnal Konstitusi. Vol. 8 No. 2. April 2011. Jakarta: Mahkamah Konstitusi of Republic of Indonesia;

Soeprapto, Maria Farida Indrati. 1998. Ilmu Perundang-Undangan, Dasar-dasar dan pembentukannya. Yogyakarta: Kanisius;

Kurniawan, Hadi. "Dinamika Putusan Mahkamah Konstitusi”. Jurnal Konstitusi. Vol. 3 No. 4. February 2008. Mahkamah Konstitusi of Republic of Indonesia;

MD, Moh Mahfud. "Gagasan Pembentukan Mahkamah Konstitusi Republik Indonesia". Jurnal Sintesis. Vol. 3 No 9. May 1999. Jakarta: Faculty of Law of Universitas Indonesia;

Naskah Akademik Undang-Undang Nomor 24 Tahun 2003 tentang Mahkamah Konstitusi.

Nope, Bill. "Pengawasan terhadap Hakim Konsti-tusi”. Jurnal Konstitusi. Vol. III No. 1. June 2010. Jakarta: Mahkamah Konstitusi of Republic of Indonesia;

Satrio. "Erga Omnes Putusan Mahkamah Konstitusi”. Jurnal Konstitusi. Vol. 11 No. V. March 2014. Jakarta: Mahkamah Konstitusi of Republic of Indonesia;

Slamet, Titon Kurnia. 2013. Mahkamah Konstitusi Republik Indonesia Sang Penjaga HAM (the guardian of human rights). Bandung: PT. Alumni;

Suharizal. “Penguatan Demokrasi Lokal Melalui Penghapusan Jabatan Wakil Kepala Daerah". Jurnal Konstitusi. Vol. 7 No. 5. October 2010. Jakarta: Mahkamah Konstitusi of Republic of Indonesia;

Sutiyoso, Bammbang. "Pemihakan Hakim Terhadap Keadilan Susbstantif Dalam Penyelesaian Sengketa Kepemilikan Atas Tanah". Jurnal Yudisial. Vol. 5 No. 3. December 2012. Jakarta: Komisi Yudisial;

Tatang, Slamet. "Mahkamah Konstitusi Sang Penjaga HAM". Jurnal Konstitusi. Vol. 11 No. 3. February 2009. Jakarta: Mahkamah Konstitusi of Republic of Indonesia. 